\title{
IMPLEMENTASI PROBABILISTIC NEURAL NETWORK DAN WORD EMBEDDING UNTUK ANALISIS SENTIMEN VAKSIN SINOVAC
}

\author{
Abdul Rahman Wahid Rapsanjani ${ }^{1}$, Erfian Junianto ${ }^{2}$ \\ 1 Universitas Adhirajasa Reswara Sanjaya \\ e-mail: muftitectona98@gmail.com \\ 2Universitas Adhirajasa Reswara Sanjaya \\ e-mail: erfian@ars.ac.id
}

\begin{abstract}
Abstrak
Penelitian ini bertujuan melakukan implementasi Probabilistic neural network dan Word Embedding dalam kasus sentiment analysis tentang tanggapan masyarakat tentang pemberian vaksin sinovac yangg diunggah di Twitter dan 3 class: positif, negative dan netral. Metode yang dipilih adalah metode klasifikasi Probabilistic Neural Network. Sebelum melakukan klasifikasi, preprocessing pada penelitian ini meliputi tokenizasi, normalisasi, menghilangkan emoticon, Convert Negasi, Stemming, Stopword Removal serta Word embedding. dataset yang digunakan berjumlah 1177 dataset dengan pembagiannya yaitu 560 dataset positif, 355 dataset negative dan 262 dataset netral. Program dirancang menggunakan Bahasa pemrograman python dengan beberapa library seperti keras, tensorflow dan pandas. Akurasi yang didapatkan pada pelatihan menggunakan Probabilistic Neural Network sebesar $91 \%$. Hasil pengujian adalah penelitian ini mampu melakukan sentiment analysis dengan kesalahan sebesar $9 \%$.
\end{abstract}

Kata kunci: Word embedding, Probabilistic Neural Network, Sentiment Analysis

\section{Abstract}

This study aims to implement the Probabilistic neural network and Word Emvedding in the case of sentiment analysis about the public's response to the administration of the Sinovac vaccine uploaded on Twitter and 3 classes: positive, negative and neutral. The method chosen is the Probabilistic neural network classification method. Before doing the classification, the preprocessing in this study includes tokenization, normalization, removing emoticons, Convert Negation, Stemming, Stopword Removal and Word embedding. The dataset used is 1177 datasets with the distribution of 560 positive datasets, 355 negative datasets and 262 neutral datasets. The program is designed using the Python programming language with several libraries such as Keras, Tensorflow and Pandas. The accuracy obtained in training using the Probabilistic neural network is $91 \%$. The test result is that this research is able to perform sentiment analysis with an error of $9 \%$.

Keywords: Word embedding, Probabilistic Neural Network, Sentiment Analysis

\section{Pendahuluan}

Coronavirus merupakan sebuah virus yang muncul di tahun 2019 di China dan sudah menyebar masuk ke Indonesia pada tahun 2020 (Setiawan, 2020). Penderita penyakit corona virus atau covid19 di Indonesia terus mengalami peningkatan sehingga menjadi penghalang bagi masyarakat melakukan aktivitas sehari-hari. Upaya yang diterapkan pemerintahan Indonesia saat coronavirus masuk ke Indonesia yaitu menerapkan Stay at Home bagi seluruh masyarakat dan diberlakukan Work From Home bagi karyawan. Adanya pemberlakuan sistem ini membuat ekonomi di Indonesia menurun (Hastuti et al., 2021), dan membuat pemerintah merubah kebijakan ini menjadi Social Distancing. Artinya, masyarakat diizinkan kembali untuk keluar dari rumah akan tetapi harus menerapkan social distancing dan selalu menggunakan masker dan mencuci tangan. Setelah diterapkan social distancing, banyak masyarakat yang tidak mematuhinya sehingga terjadi peningkatan jumlah orang positif corona di Indonesia khususnya terjadi pada akhir tahun 2020 sampai tahun 2021 ini 
(Fajar et al., 2021). Negeri china akhirnya menemukan vaksin untuk penyakit corona virus dan segera disebarluaskan ke banyak negara. Vaksin ini dianggap menjadi solusi bagi Indonesia untuk tetap dapat melakukan aktivitas seperti biasanya dan tetap kebal terhadap penyakit corona virus. Pemberian vaksinasi ini bersifat wajib bagi seluruh masyarakat, akan tetapi banyak masyarakat yang takut menerima vaksin ini. Hal tersebut dikarenakan ketakutan masyarakat akan efek yang ditimbulkannya (Dini, 2021). Sehingga adanya vaksinasi ini memberikan banyak tanggapan dari masyarakat melalui media social seperti twitter dan Instagram.

Tanggapan yang ada dapat berupa tanggapan negative, netral maupun positif. Tanggapan-tanggapan ini dapat mempengaruhi masyarakat dalam kesediaannya menerima vaksinasi, sehingga perlu diklasifikasikan sentiment analysis dari respon masyarakat di Indonesia mengenai vaksinasi ini agar tidak menjadi hoax atau tidak memberikan kesalahan persepsi bagi masyarakat umum. Sentiment analyisis termasuk kedalam text mining dimana text mining pernah dilakukan penelitian yang melakukan deteksi emosi pada social media menggunakan particle swarm optimasi dan naïve bayes classifier (Junianto \& Rachman, 2019).

Penelitian ini bertujuan melakukan analisis sentimen dalam pemberian vaksin sinovac. pembahasan ini pernah dilakukan penelitian sebelumnya dengan judul Analisis Sentimen Pro dan Kontra Pemberian Vaksin Covid 19. Penelitian ini bertujuan untuk menganalisis tanggapan masyarakat terhadap wacana vaksinasi dengan mengklasifikasikan tanggapan tersebut menjadi tanggapan positif dan negative menggunakan metode Latent Dirichlet Allocation (LDA) untuk mengetahui topik pembicaraan apa yang sering dibicarakan oleh masyarakat mengenai wacana vaksinasi. Hasil analisis menunjukkan bahwa tanggapan masyarakat lebih positif terhadap wacana $(30 \%)$ dibandingkan tanggapan negatif (Rachman \& Pramana, 2020). Kata- kata yang paling sering muncul juga menunjukkan bahwa terdapat lebih banyak kata dengan sentimen positif daripada katakata dengan sentimen negatif. Analisis sentiment belum pernah dilakukan menggunakan metode Probabilistic neural network, metode ini dikenal cukup baik dalam melakukan analisis sentiment seperti pada penelitian sebelumnya mengenai sentiment analysis komplain mahasiswa di kampus dengan hasil akurasi sebesar $90 \%$ (Sarwani \& Mahmudy, 2016). PNN juga menghasilkan akurasi yang baik dalam melakukan identifikasi dan deteksi tumor pada otak dengan rata-rata akurasi sebanyak $70 \%$ (Shree \& Kumar, 2018), sedangkan word embedding mempunyai kinerja yang baik dalam melakukan preprocessing text dan dapat membantu metode untuk klasifikasi seperti pada penelitian yang melakukan sentiment analysis pada review produk dan terlihat bahwa word embedding membantu dalam melakukan preprocessing text sehingga menghasilkan akurasi maksimal sebesar 97\% (Onan, 2020).

Berdasarkan penelitian sebelumnya, maka penulis menerapkan metode PNN dan word embedding untuk menguji performansi dari dataset tanggapan masyarakat mengenai vaksin sinovac yang ada di twitter. Data yang digunakan sebanyak 3000 dataset yang diambil dari Kaggle. Preprocessing yang dilakukan yaitu proses tokenizing, normalisasi, convert negasi, menghilangkan emoticon dan stopword removal. Pengujian akan dilakukan untuk mendapatkan nilai precision, recall, f1 score dan confussion matrix. Jumlah class pada penelitian ini yaitu tiga kelas yang terdiri dari class positif, class negative, dan class netral.

\section{Metode Penelitian}

Pada sistem yang dibangun, skenario yang terjadi apabila pengguna mengakses sistem dan memasukan gambar mobil akan diketahui jenis mobil tersebut serta besaran akurasinya. Adapun prosedur dari sistem dapat dilihat pada gambar 1 . 


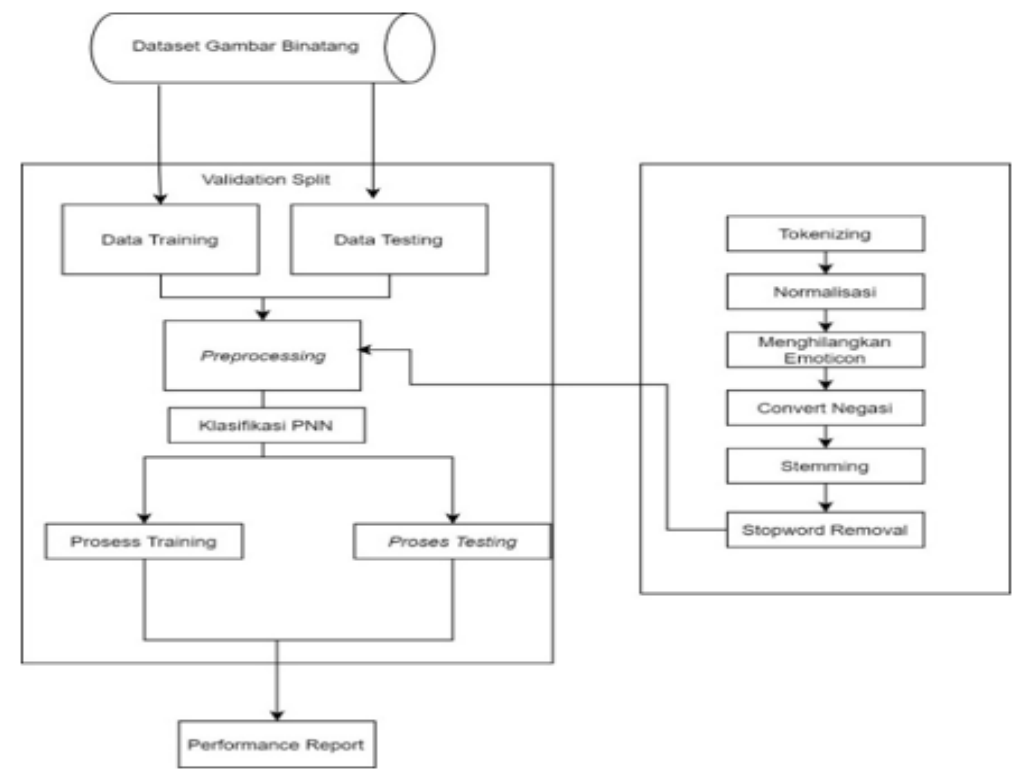

Gambar 1. Alur Prosedur Sistem Yang Dibangun

Gambar 1. menjelaskan proses yang dilakukan pada penelitian ini. Berikut merupakan penjelasannya:

a. Dataset vaksin sinovac yang didapatkan merupakan data public yang bersumber dari Kaggle dengan link berikut: https://www.kaggle.com/rpnugroho/indon esian-vaccination-tweets

b. Melakukan split dataset, nantinya akan dilakukan cross validation yaitu merubah porsi atau pembagian setiap dataset pada proses training dan testing. Misalkan $70: 30$, atau $80: 30$

c. Melakukan preprosessing text untuk membersihkan data karena dataset yang dimiliki masih kotor. Preprocessing yang dilakukan adalah tokenizing, normalisasi, menghilangkan emoticon, convert negasi, stemming dan stopword removal dan word embedding.

d. Setelah dilakukan preproceesing text selanjutnya dilakukan proses klasifikasi menggunakan metode PNN dengan output mencari nilai bobot dari setiap class

e. Setelah dilakukan proses learning, akan muncul performance evaluasi.

\section{Hasil dan Pembahasan}

Bab ini akan membahas pembuatan sistem, alat yang digunakan, hasil pengujian dan analisis sistem. Analisis dilakukan untuk mengetahui kelebihan dan kekurangan dari model yang dibuat.

\subsection{Perangkat Lunak yang Digunakan}

Pada pembuatan simulasi untuk implementasi PNN pada kasus sentiment analisis ini memerlukan beberapa perangkat lunak sebagai berikut:

a. Sistem Operasi

Proses pembuatan sistem ini dilakukan menggukan system operasi windows.

b. Laptop/PC

Laptop/PC digunakan untuk melakukan penulisan program, dan pengaturan pengaturan source code di Bahasa pemrograman python.

c. Browser

Browser digunakan untuk pengetesan dan pengecheckkan implementasi model.

d. Python

Proses pembuatan aplikasi IT Helpdesk dengan pengkodingan yang berbahasa pemrograman Python 3.7.

\subsection{Library}

Pada implementasi model Probabilistic neural network dan Word embedding untuk kasus analisis sentiment tanggapan tentang vaksin sinovac ini, dibutuhkan library yang mendukung. Pada penelitian ini, akan dibuat sebuah simulasi dalam menguji model Probabilistic neural network untuk menghasilkan akurasi yang baik dengan menggunakan Bahasa pemrograman python dan library seperti pada Tabel 1. 
Tabel 1. Teknologi Yang Digunakan

\begin{tabular}{|l|l|l|}
\hline No & $\begin{array}{l}\text { Nama } \\
\text { Library }\end{array}$ & Kegunaan \\
\hline 1 & Numpy & $\begin{array}{l}\text { Membaca dataset, } \\
\text { memproses dataset }\end{array}$ \\
\hline 2 & NLTK & $\begin{array}{l}\text { Melakukan } \\
\text { preprocessing seperti } \\
\text { tokenizer dan yang } \\
\text { lainnya }\end{array}$ \\
\hline 3 & Keras & $\begin{array}{l}\text { Library untuk word } \\
\text { PNN }\end{array}$ \\
\hline 4 & Tensorflow & $\begin{array}{l}\text { Library untuk } \\
\text { implementasi PNN }\end{array}$ \\
\hline 5 & Sastrawi & $\begin{array}{l}\text { Library untuk proses } \\
\text { stemming dimana } \\
\text { library ini menyimpan } \\
\text { kata dasar sesuai } \\
\text { Bahasa Indonesia. }\end{array}$ \\
\hline 6 & Seaborn & $\begin{array}{l}\text { Library untuk } \\
\text { memunculkan grafik }\end{array}$ \\
\hline 7 & Python 3.7 & $\begin{array}{l}\text { Environment python } \\
\text { yang support dengan } \\
\text { library yang } \\
\text { dibutuhkan }\end{array}$ \\
\hline 8 & Gensim & $\begin{array}{l}\text { Library untuk Fasttext } \\
\text { (Word embedding) }\end{array}$ \\
\hline
\end{tabular}

Proses dari model yang diusulkan sesuai dengan Gambar 1. berikut penjelasannya yang diimplementasikan dengan teknologi pada Tabel IV.1.

a. Dataset

Dataset yang digunakan pada penelitian ini disimpan dalam format Comma Separated Values (CSV) dan berjumlah 1177 dataset, sebagai contoh berikut ditampilkan Sebagian dataset pada Tabel 2. dan lebih lengkapnya terdapat di Lampiran A1.

Tabel 2. Dataset

\begin{tabular}{|l|l|}
\hline \multicolumn{1}{|c|}{ ID } & \multicolumn{1}{c|}{ Text } \\
\hline 1348286903527768 & \#vaksin untuk \\
065 & \#indonesia \\
\hline 1348302168248340 & Gak Kenal maka \\
481 & Gak Kebal. Vaksin \\
& jadi bukti manusia \\
& berjuang menjaga \\
& eksistensinya di \\
& dunia ini. \\
\hline 1348307055040348 & Sistem satu data \\
160 & mendukung \\
& Vaksinasi di \\
& Indonesia \#Vaksin \\
& \#Covid19 \\
& \#CoronaVirus \\
& \#Kesehatan \\
\hline
\end{tabular}

\begin{tabular}{|l|l|}
\hline 1348322660925669 & Siap menerima \\
& vaksin covid 19 \\
& \#vaksinhalal \\
& \#vaksinsiap34prop \\
& insi \\
& \#vaksicovid19 \\
& \#jokowidodo... \\
\hline
\end{tabular}

b. Tahap Preprocessing

Tahap ini dilakukan untuk membersihkan data. Dataset yang kita ambil dari repository dengan bentuk original tentunya belum tentu siap untuk digunakan untuk membedakan mana tweet positif, negative dan netral. Data kotor tersebut seperti terdapat teks kosong, teks duplikat, dan kata yang mempunyai multi penafsiran. Berikut gambar 2 merupakan tahap preprocessing text pada penelitian ini.

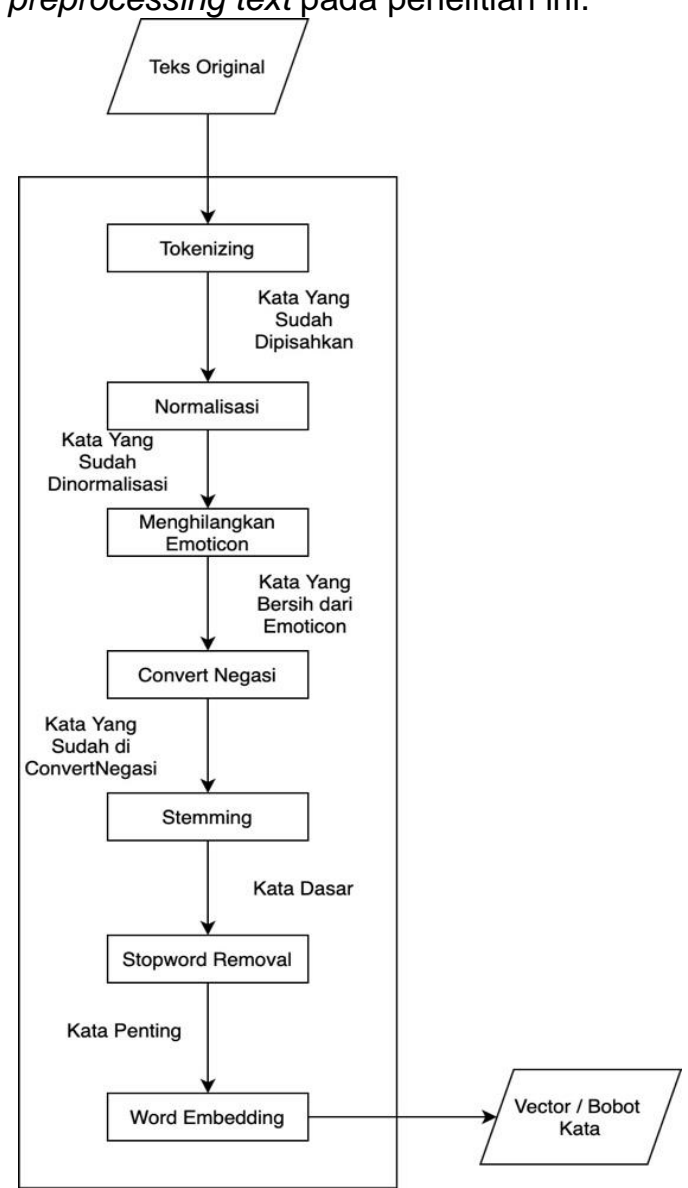

Gambar 2. Proses Preprocessing 
c. Tokenizing

\begin{tabular}{|c|c|c|}
\hline ID & Text & $\begin{array}{c}\text { Hasil } \\
\text { Tokenizing }\end{array}$ \\
\hline $\begin{array}{l}1348286903 \\
527768065\end{array}$ & $\begin{array}{l}\text { \#vaksin } \\
\text { untuk } \\
\text { \#indonesia } \\
\text {;: }\end{array}$ & $\begin{array}{l}\text { \#vaksin } \\
\text { untuk } \\
\text { Indonesia } \\
\text { (;) }\end{array}$ \\
\hline $\begin{array}{l}1348302168 \\
248340481\end{array}$ & $\begin{array}{l}\text { Gak Kenal } \\
\text { maka Gak } \\
\text { Kebal. } \\
\text { Vaksin jadi } \\
\text { bukti } \\
\text { manusia } \\
\text { berjuang } \\
\text { menjaga } \\
\text { eksistensin } \\
\text { ya di dunia } \\
\text { ini. } \\
\text { HEHEHE } \\
\text { :D }\end{array}$ & $\begin{array}{l}\text { Gak } \\
\text { Kenal } \\
\text { Maka } \\
\text { Gak } \\
\text { Kebal. } \\
\text { Vaksin } \\
\text { Jadi } \\
\text { Bukti } \\
\text { Manusia } \\
\text { Berjuang } \\
\text { Menjaga } \\
\text { Eksistensin } \\
\text { ya } \\
\text { Di } \\
\text { Dunia } \\
\text { Ini. } \\
\text { HEHEHE } \\
\text { :D }\end{array}$ \\
\hline $\begin{array}{l}1348307055 \\
040348160\end{array}$ & $\begin{array}{l}\text { Sistem satu } \\
\text { data } \\
\text { mendukung } \\
\text { Vaksinasi di } \\
\text { Indonesia } \\
\text { =D \#Vaksin } \\
\text { \#Covid19 } \\
\text { \#CoronaVir } \\
\text { us } \\
\text { \#Kesehatan }\end{array}$ & $\begin{array}{l}\text { Sistem } \\
\text { Satu } \\
\text { Data } \\
\text { mendukung } \\
\text { Vaksinasi } \\
\text { di } \\
\text { Indonesia } \\
=\text { D } \\
\text { \#Vaksin } \\
\text { \#Covid19 } \\
\text { \#CoronaVir } \\
\text { us } \\
\text { \#Kesehatan }\end{array}$ \\
\hline $\begin{array}{l}1348322660 \\
925669377\end{array}$ & $\begin{array}{l}\text { Siap } \\
\text { menerima } \\
\text { vaksin } \\
\text { covid } 19 \\
\text { \#vaksinhala } \\
\text { \#vaksinsiap } \\
\text { 34propinsi } \\
\text { \#vaksicovid } \\
19 \\
\text { \#jokowidod } \\
\text { O... }\end{array}$ & $\begin{array}{l}\text { Siap } \\
\text { menerima } \\
\text { vaksin } \\
\text { covid } \\
19 \\
\text { \#vaksinhala } \\
\text { I } \\
\text { \#vaksinsiap } \\
34 \text { propinsi } \\
\text { \#vaksicovid } \\
19 \\
\text { \#jokowidod } \\
\text { O... }\end{array}$ \\
\hline
\end{tabular}

d. Normalisasi

\begin{tabular}{|c|c|c|}
\hline ID & Text & $\begin{array}{c}\text { Hasil } \\
\text { Normalisa } \\
\text { si }\end{array}$ \\
\hline $\begin{array}{l}1348286903 \\
527768065\end{array}$ & $\begin{array}{l}\text { \#vaksin } \\
\text { untuk } \\
\text { Indonesia } \\
\text { :; }\end{array}$ & $\begin{array}{l}\text { \#vaksin } \\
\text { untuk } \\
\text { Indonesia } \\
\text { :) }\end{array}$ \\
\hline $\begin{array}{l}1348302168 \\
248340481\end{array}$ & $\begin{array}{l}\text { Gak } \\
\text { Kenal } \\
\text { Maka } \\
\text { Gak } \\
\text { Kebal. } \\
\text { Vaksin } \\
\text { Jadi } \\
\text { Bukti } \\
\text { Manusia } \\
\text { Berjuang } \\
\text { Menjaga } \\
\text { Eksistensin } \\
\text { ya } \\
\text { Di } \\
\text { Dunia } \\
\text { Ini. } \\
\text { HEHEHE } \\
\text { :D }\end{array}$ & $\begin{array}{l}\text { Tidak } \\
\text { Kenal } \\
\text { Maka } \\
\text { Tidak } \\
\text { Kebal. } \\
\text { Vaksin } \\
\text { Jadi } \\
\text { Bukti } \\
\text { Manusia } \\
\text { Berjuang } \\
\text { Menjaga } \\
\text { Eksistensin } \\
\text { ya } \\
\text { Di } \\
\text { Dunia } \\
\text { Ini. } \\
\text { HEHEHE } \\
\text { :D }\end{array}$ \\
\hline $\begin{array}{l}1348307055 \\
040348160\end{array}$ & $\begin{array}{l}\text { Sistem } \\
\text { Satu } \\
\text { Data } \\
\text { mendukung } \\
\text { Vaksinasi } \\
\text { di } \\
\text { Indonesia } \\
=D \\
\text { \#Vaksin } \\
\text { \#Covid19 } \\
\text { \#CoronaVir } \\
\text { us } \\
\text { \#Kesehatan }\end{array}$ & $\begin{array}{l}\text { Sistem } \\
\text { Satu } \\
\text { Data } \\
\text { mendukung } \\
\text { Vaksinasi } \\
\text { di } \\
\text { Indonesia } \\
=\text { D } \\
\text { \#Vaksin } \\
\text { \#Covid19 } \\
\text { \#CoronaVir } \\
\text { us } \\
\text { \#Kesehatan }\end{array}$ \\
\hline $\begin{array}{l}1348322660 \\
925669377\end{array}$ & $\begin{array}{l}\text { Siap } \\
\text { menerima } \\
\text { vaksin } \\
\text { covid } \\
19 \\
\text { \#vaksinhala } \\
\text { I } \\
\text { \#vaksinsiap } \\
34 \text { propinsi } \\
\text { \#vaksicovid } \\
19 \\
\text { \#jokowidod } \\
\text { O... }\end{array}$ & $\begin{array}{l}\text { Siap } \\
\text { menerima } \\
\text { vaksin } \\
\text { covid } \\
19 \\
\text { \#vaksinhala } \\
\text { I } \\
\text { \#vaksinsiap } \\
34 \text { propinsi } \\
\text { \#vaksicovid } \\
19 \\
\text { \#jokowidod } \\
\text { O... }\end{array}$ \\
\hline
\end{tabular}


e. Menghilangkan Emoticon

Tabel 5. Hasil Menghilangkan Emoticon

\begin{tabular}{|c|c|c|}
\hline ID & Text & $\begin{array}{c}\text { Hasil } \\
\text { Normalisa } \\
\text { si }\end{array}$ \\
\hline $\begin{array}{l}1348286903 \\
527768065\end{array}$ & $\begin{array}{l}\text { \#vaksin } \\
\text { untuk } \\
\text { Indonesia } \\
\text {;: }\end{array}$ & $\begin{array}{l}\text { \#vaksin } \\
\text { untuk } \\
\text { Indonesia }\end{array}$ \\
\hline $\begin{array}{l}1348302168 \\
248340481\end{array}$ & $\begin{array}{l}\text { Tidak } \\
\text { Kenal } \\
\text { Maka } \\
\text { Tidak } \\
\text { Kebal. } \\
\text { Vaksin } \\
\text { Jadi } \\
\text { Bukti } \\
\text { Manusia } \\
\text { Berjuang } \\
\text { Menjaga } \\
\text { Eksistensin } \\
\text { ya } \\
\text { Di } \\
\text { Dunia } \\
\text { Ini. } \\
\text { HEHEHE } \\
\text { :D }\end{array}$ & $\begin{array}{l}\text { Tidak } \\
\text { Kenal } \\
\text { Maka } \\
\text { Tidak } \\
\text { Kebal. } \\
\text { Vaksin } \\
\text { Jadi } \\
\text { Bukti } \\
\text { Manusia } \\
\text { Berjuang } \\
\text { Menjaga } \\
\text { Eksistensin } \\
\text { ya } \\
\text { Di } \\
\text { Dunia } \\
\text { Ini. } \\
\text { HEHEHE }\end{array}$ \\
\hline $\begin{array}{l}1348307055 \\
040348160\end{array}$ & $\begin{array}{l}\text { Sistem } \\
\text { Satu } \\
\text { Data } \\
\text { mendukung } \\
\text { Vaksinasi } \\
\text { di } \\
\text { Indonesia } \\
=\text { D } \\
\text { \#Vaksin } \\
\text { \#Covid19 } \\
\text { \#CoronaVir } \\
\text { us } \\
\text { \#Kesehatan }\end{array}$ & $\begin{array}{l}\text { Sistem } \\
\text { Satu } \\
\text { Data } \\
\text { mendukung } \\
\text { Vaksinasi } \\
\text { di } \\
\text { Indonesia } \\
\text { \#Vaksin } \\
\text { \#Covid19 } \\
\text { \#CoronaVir } \\
\text { us } \\
\text { \#Kesehatan }\end{array}$ \\
\hline $\begin{array}{l}1348322660 \\
925669377\end{array}$ & $\begin{array}{l}\text { Siap } \\
\text { menerima } \\
\text { vaksin } \\
\text { covid } \\
19 \\
\text { \#vaksinhala } \\
\text { I } \\
\text { \#vaksinsiap } \\
\text { 34propinsi } \\
\text { \#vaksicovid } \\
19 \\
\text { \#jokowidod } \\
\text { O... }\end{array}$ & $\begin{array}{l}\text { Siap } \\
\text { menerima } \\
\text { vaksin } \\
\text { covid } \\
19 \\
\text { \#vaksinhala } \\
\text { I } \\
\text { \#vaksinsiap } \\
34 \text { propinsi } \\
\text { \#vaksicovid } \\
19 \\
\text { \#jokowidod } \\
\text { O... }\end{array}$ \\
\hline
\end{tabular}

f. Convert negasi

\begin{tabular}{|c|c|c|}
\hline 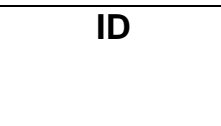 & Text & $\begin{array}{c}\text { Hasil } \\
\text { Normalisa } \\
\text { si }\end{array}$ \\
\hline $\begin{array}{l}1348286903 \\
527768065\end{array}$ & $\begin{array}{l}\text { \#vaksin } \\
\text { untuk } \\
\text { Indonesia }\end{array}$ & $\begin{array}{l}\text { \#vaksin } \\
\text { untuk } \\
\text { Indonesia }\end{array}$ \\
\hline $\begin{array}{l}1348302168 \\
248340481\end{array}$ & $\begin{array}{l}\text { Tidak } \\
\text { Kenal } \\
\text { Maka } \\
\text { Tidak } \\
\text { Kebal. } \\
\text { Vaksin } \\
\text { Jadi } \\
\text { Bukti } \\
\text { Manusia } \\
\text { Berjuang } \\
\text { Menjaga } \\
\text { Eksistensin } \\
\text { ya } \\
\text { Di } \\
\text { Dunia } \\
\text { Ini. } \\
\text { HEHEHE }\end{array}$ & $\begin{array}{l}\text { TidakKenal } \\
\text { Maka } \\
\text { TidakKebal. } \\
\text { Vaksin } \\
\text { Jadi } \\
\text { Bukti } \\
\text { Manusia } \\
\text { Berjuang } \\
\text { Menjaga } \\
\text { Eksistensin } \\
\text { ya } \\
\text { Di } \\
\text { Dunia } \\
\text { Ini. } \\
\text { HEHEHE }\end{array}$ \\
\hline $\begin{array}{l}1348307055 \\
040348160\end{array}$ & $\begin{array}{l}\text { Sistem } \\
\text { Satu } \\
\text { Data } \\
\text { mendukung } \\
\text { Vaksinasi } \\
\text { di } \\
\text { Indonesia } \\
\text { \#Vaksin } \\
\text { \#Covid19 } \\
\text { \#CoronaVir } \\
\text { us } \\
\text { \#Kesehatan }\end{array}$ & $\begin{array}{l}\text { Sistem } \\
\text { Satu } \\
\text { Data } \\
\text { mendukung } \\
\text { Vaksinasi } \\
\text { di } \\
\text { Indonesia } \\
\text { \#Vaksin } \\
\text { \#Covid19 } \\
\text { \#CoronaVir } \\
\text { us } \\
\text { \#Kesehatan }\end{array}$ \\
\hline $\begin{array}{l}1348322660 \\
925669377\end{array}$ & $\begin{array}{l}\text { Siap } \\
\text { menerima } \\
\text { vaksin } \\
\text { covid } \\
19 \\
\text { \#vaksinhala } \\
\text { I } \\
\text { \#vaksinsiap } \\
\text { 34propinsi } \\
\text { \#vaksicovid } \\
19 \\
\text { \#jokowidod } \\
\text { o... }\end{array}$ & $\begin{array}{l}\text { Siap } \\
\text { menerima } \\
\text { vaksin } \\
\text { covid } \\
19 \\
\text { \#vaksinhala } \\
\text { I } \\
\text { \#vaksinsiap } \\
\text { 34propinsi } \\
\text { \#vaksicovid } \\
19 \\
\text { \#jokowidod } \\
\text { O... }\end{array}$ \\
\hline
\end{tabular}


g. Stemming

\begin{tabular}{|c|c|c|}
\hline Id & Teks & $\begin{array}{c}\text { Hasil } \\
\text { Stemming }\end{array}$ \\
\hline $\begin{array}{l}1348286903 \\
527768065\end{array}$ & $\begin{array}{l}\text { \#vaksin } \\
\text { untuk } \\
\text { Indonesia }\end{array}$ & $\begin{array}{l}\text { \#vaksin } \\
\text { untuk } \\
\text { Indonesia }\end{array}$ \\
\hline $\begin{array}{l}1348302168 \\
248340481\end{array}$ & $\begin{array}{l}\text { TidakKenal } \\
\text { Maka } \\
\text { TidakKebal. } \\
\text { Vaksin } \\
\text { Jadi } \\
\text { Bukti } \\
\text { Manusia } \\
\text { Berjuang } \\
\text { Menjaga } \\
\text { Eksistensin } \\
\text { ya } \\
\text { Di } \\
\text { Dunia } \\
\text { Ini. } \\
\text { HEHEHE }\end{array}$ & $\begin{array}{l}\text { TidakKenal } \\
\text { Maka } \\
\text { TidakKebal. } \\
\text { Vaksin } \\
\text { Jadi } \\
\text { Bukti } \\
\text { Manusia } \\
\text { Berjuang } \\
\text { jaga } \\
\text { Eksistensi } \\
\text { Di } \\
\text { Dunia } \\
\text { Ini. } \\
\text { HEHEHE }\end{array}$ \\
\hline $\begin{array}{l}1348307055 \\
040348160\end{array}$ & $\begin{array}{l}\text { Sistem } \\
\text { Satu } \\
\text { Data } \\
\text { mendukung } \\
\text { Vaksinasi } \\
\text { di } \\
\text { Indonesia } \\
\text { \#Vaksin } \\
\text { \#Covid19 } \\
\text { \#CoronaVir } \\
\text { us } \\
\text { \#sehat }\end{array}$ & $\begin{array}{l}\text { Sistem } \\
\text { Satu } \\
\text { Data } \\
\text { mendukung } \\
\text { Vaksinasi } \\
\text { di } \\
\text { Indonesia } \\
\text { \#Vaksin } \\
\text { \#Covid19 } \\
\text { \#CoronaVir } \\
\text { us } \\
\text { \#sehat }\end{array}$ \\
\hline $\begin{array}{l}1348322660 \\
925669377\end{array}$ & $\begin{array}{l}\text { Siap } \\
\text { menerima } \\
\text { vaksin } \\
\text { covid } \\
19 \\
\text { \#vaksinhala } \\
\text { I } \\
\text { \#vaksinsiap } \\
34 \text { propinsi } \\
\text { \#vaksicovid } \\
19 \\
\text { \#jokowidod } \\
\text { O... }\end{array}$ & $\begin{array}{l}\text { Siap } \\
\text { terima } \\
\text { vaksin } \\
\text { covid } \\
19 \\
\text { \#vaksinhala } \\
\text { I } \\
\text { \#vaksinsiap } \\
\text { 34propinsi } \\
\text { \#vaksicovid } \\
19 \\
\text { \#jokowidod } \\
\text { O... }\end{array}$ \\
\hline $\begin{array}{l}1348425614 \\
584266753\end{array}$ & $\begin{array}{l}\text { Apa } \\
\text { Bedanya } \\
\text { Vaksin } \\
\text { China } \\
\text { Sinovac } \\
\text { dan } \\
\text { Sinopharm } \\
\text { serta } \\
\text { Merek } \\
\text { Lain? }\end{array}$ & $\begin{array}{l}\text { Apa } \\
\text { Beda } \\
\text { Vaksin } \\
\text { China } \\
\text { Sinovac } \\
\text { dan } \\
\text { Sinopharm } \\
\text { serta } \\
\text { Merek } \\
\text { Lain? }\end{array}$ \\
\hline
\end{tabular}

\begin{tabular}{|c|c|c|}
\hline & $\begin{array}{l}\text { \#Vaksin } \\
\text { \#Perusaha } \\
\text { anfarmasi } \\
\text { \#Virus } \\
\text { \#Farmasi... }\end{array}$ & $\begin{array}{l}\text { \#Vaksin } \\
\text { \#Perusaha } \\
\text { anfarmasi } \\
\text { \#Virus } \\
\text { \#Farmasi... }\end{array}$ \\
\hline $\begin{array}{l}1348427123 \\
594207233\end{array}$ & $\begin{array}{l}\text { Dua } \\
\text { Lagi } \\
\text { Obat } \\
\text { yang } \\
\text { Dapat } \\
\text { Selamatkan } \\
\text { Nyawa } \\
\text { Pasien } \\
\text { COVID-19 } \\
\text { Ditemukan } \\
\text { \#lnfus } \\
\text { \#Virus } \\
\text { \#Wabah } \\
\text { \#Radang } \\
\text { \#Vaksin... }\end{array}$ & $\begin{array}{l}\text { Dua } \\
\text { Lagi } \\
\text { Obat } \\
\text { yang } \\
\text { Dapat } \\
\text { Selamat } \\
\text { Nyawa } \\
\text { Pasien } \\
\text { COVID-19 } \\
\text { temu } \\
\text { \#Infus } \\
\text { \#Virus } \\
\text { \#Wabah } \\
\text { \#Radang } \\
\text { \#Vaksin... }\end{array}$ \\
\hline $\begin{array}{l}1348434452 \\
775657475\end{array}$ & $\begin{array}{l}\text { Vaksin } \\
\text { buatan } \\
\text { Tiongkok } \\
\text { kembali } \\
\text { dipertanyak } \\
\text { an, } \\
\text { orang } \\
\text { tua } \\
\text { tidakboleh } \\
\text { suntik! }\end{array}$ & $\begin{array}{l}\text { Vaksin } \\
\text { buat } \\
\text { Tiongkok } \\
\text { kembali } \\
\text { tanya, } \\
\text { orang } \\
\text { tua } \\
\text { tidakboleh } \\
\text { suntik! }\end{array}$ \\
\hline $\begin{array}{l}1348434452 \\
775657337\end{array}$ & $\begin{array}{l}\text { Walaupun } \\
\text { di } \\
\text { vaksin, } \\
\text { tetangga } \\
\text { saya } \\
\text { masih } \\
\text { terkena } \\
\text { covid } \\
\text { juga } \\
\text { tuh } \\
\text { \#vaksingag } \\
\text { al }\end{array}$ & $\begin{array}{l}\text { Walaupun } \\
\text { di } \\
\text { vaksin, } \\
\text { tetangga } \\
\text { saya } \\
\text { masih } \\
\text { terkena } \\
\text { covid } \\
\text { juga } \\
\text { tuh } \\
\text { \#vaksingag } \\
\text { al }\end{array}$ \\
\hline
\end{tabular}

h. Stop word removal

Tabel 8. Hasil Stop word Removal

\begin{tabular}{|l|l|l|}
\hline \multicolumn{1}{|c|}{ Id } & $\begin{array}{l}\text { Hasil } \\
\text { Stemming }\end{array}$ & $\begin{array}{l}\text { Hasil Stop } \\
\text { word } \\
\text { Removal }\end{array}$ \\
\hline $\begin{array}{l}1348286903 \\
527768065\end{array}$ & $\begin{array}{l}\text { \#vaksin } \\
\text { untuk } \\
\text { Indonesia }\end{array}$ & $\begin{array}{l}\text { \#vaksin } \\
\text { Indonesia }\end{array}$ \\
\hline 1348302168 & TidakKenal & TidakKenal \\
248340481 & Maka & $\begin{array}{l}\text { TidakKebal. } \\
\text { Vaksin }\end{array}$ \\
& TidakKebal. \\
& Vaksin & Bukti \\
& Jadi & Manusia \\
& Bukti & Berjuang \\
\hline
\end{tabular}




\begin{tabular}{|l|l|l|}
\hline & Manusia & jaga \\
& Berjuang & Eksistensi \\
& jaga & Dunia \\
& Eksistensi & \\
& Di & \\
& Dunia & \\
& Ini. & \\
& HEHEHE & \\
& & \\
\hline 1348307055 & Sistem & Sistem \\
040348160 & Satu & Satu \\
& Data & Data \\
& mendukung & mendukung \\
& Vaksinasi & Vaksinasi \\
& di & Indonesia \\
& Indonesia & \#Vaksin \\
& \#Vaksin & \#Covid19 19 \\
& \#Covid19 & \#CoronaVir \\
& \#CoronaVir & us \\
& us & \#sehat \\
& \#sehat & \\
\hline 1348322660 & Siap & Siap \\
terima & terima \\
& vaksin & vaksin \\
& covid & covid \\
& 19 & 19 \\
& \#vaksinhala & \#vaksinhala \\
& I & I \\
& \#vaksinsiap & \#vaksinsiap \\
& 34propinsi & 34propinsi \\
& \#vaksicovid & \#vaksicovid \\
& 19 & 19 \\
& \#jokowidod & \#jokowidod \\
& O... & O... \\
\hline & & \\
\hline
\end{tabular}

\section{i. Word embedding}

Word embedding adalah istilah yang digunakan untuk teknik mengubah sebuah kata menjadi sebuah vektor atau array yang terdiri dari kumpulan angka. Ketika membuat model machine learning yang menerima input sebuah teks, tentu machine learning tidak bisa langsung menerima mentahmentah teks yang kita miliki, kata tersebut harus diubah dulu menjadi angka dengan acuan sebuah kamus kata. Biasanya jika tidak menggunakan word embedding, setiap kata akan diubah menjadi angka dalam bentuk Integer sesuai dengan posisi angka tersebut dalam kamus, misalkan kata "Sembuh" diubah menjadi angka "4" dan kata "Meninggal" diubah menjadi angka "7". Angka tersebut kita ubah lagi menjadi sebuah vektor (array 1 dimensi) yang memiliki panjang sepanjang banyak kata yang kita miliki di kamus. Array tersebut hanya akan bernilai 1 atau 0 (disebut one hot encoding). Nilai 1 diposisikan pada indeks yang merupakan nomor kata tersebut sedangkan elemen lainnya bernilai 0 .

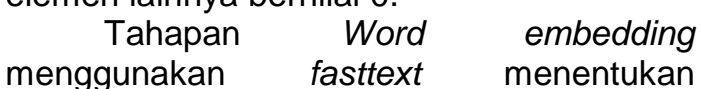

parameter betikut:

a. sg: parameter ini menentukan learning algorithm apa yang akan digunakan. Terdapat 2 pilihan learning algorithm, skip-gram atau CBOW.

b. Size: parameter ini menentukan dimensi dari vector.

c. Window: parameter ini menentukan jumlah kata sebelum dan sesudah kata tertentu yang digunakan sebagai pertimbangan konteks dalam satu kalimat.

d. Min_count: parameter ini menentukan jumlah minimum kemunculan suatu kata agar kata tersebut tidak diabaikan

e. Iter: parameter ini menentukan jumlah iterasi dilakukannya training.

f. Min_n: parameter ini menentukan panjang minimum character $n$-gram yang akan digunakan untuk training representasi kata.

g. Max_n: parameter ini menentukan panjang maksimum character n-gram yang akan digunakan untuk traning representasi kata.

Berikut merupakan contoh kata yang akan diproses dengan fasttext.

Tabel 9. Hasil Word embedding

\begin{tabular}{|l|l|l|}
\hline \multicolumn{1}{|c|}{ Id } & Teks & $\begin{array}{c}\text { Bob } \\
\text { ot } \\
\text { Kata } \\
\text { dala } \\
\text { m } \\
\text { Kam } \\
\text { us }\end{array}$ \\
\hline 1348286903527 & \#vaksin & 0.22 \\
768065 & Indonesia & 0.03 \\
& & 1 \\
\hline 1348302168248 & TidakKenal & 0.45 \\
340481 & TidakKebal. & 2 \\
& Vaksin & 0.32 \\
& Bukti & 0.22 \\
& Manusia & 0.04 \\
& Berjuang & 9 \\
& jaga & 0.11 \\
& Eksistensi & 0.12 \\
& Dunia & 0.45 \\
& & 0.12 \\
& & 0 \\
& & 0.03 \\
& & 3 \\
& & \\
\hline
\end{tabular}




\begin{tabular}{|c|c|c|}
\hline $\begin{array}{l}1348307055040 \\
348160\end{array}$ & $\begin{array}{l}\text { Sistem } \\
\text { Satu } \\
\text { Data } \\
\text { mendukung } \\
\text { Vaksinasi } \\
\text { Indonesia } \\
\text { \#Vaksin } \\
\text { \#Covid19 } \\
\text { \#CoronaVirus } \\
\text { \#sehat }\end{array}$ & $\begin{array}{l}0.35 \\
2 \\
0.52 \\
0.02 \\
2 \\
0.14 \\
9 \\
0.22 \\
0.03 \\
1 \\
0.22 \\
0.12 \\
0 \\
0.12 \\
1 \\
0.34 \\
2\end{array}$ \\
\hline $\begin{array}{l}1348322660925 \\
669377\end{array}$ & $\begin{array}{l}\text { Siap } \\
\text { terima } \\
\text { vaksin } \\
\text { covid } \\
19 \\
\text { \#vaksinhalal } \\
\text { \#vaksinsiap34 } \\
\text { propinsi } \\
\text { \#vaksicovid19 } \\
\text { \#jokowidodo... }\end{array}$ & $\begin{array}{l}0.35 \\
2 \\
0.52 \\
0.02 \\
2 \\
0.20 \\
0.22 \\
0.22 \\
1 \\
0.22 \\
0.22 \\
0 \\
0.12 \\
1\end{array}$ \\
\hline $\begin{array}{l}1348425614584 \\
266753\end{array}$ & $\begin{array}{l}\text { Apa } \\
\text { Beda } \\
\text { Vaksin } \\
\text { China } \\
\text { Sinovac } \\
\text { Sinopharm } \\
\text { Merek } \\
\text { Lain } \\
\text { \#Vaksin } \\
\text { \#Perusahaanfa } \\
\text { rmasi \#Virus } \\
\text { \#Farmasi }\end{array}$ & $\begin{array}{l}0.35 \\
2 \\
0.52 \\
0.22 \\
0.45 \\
0 \\
0.22 \\
0.32 \\
1 \\
0.32 \\
0.32 \\
0 \\
0.21 \\
0.12 \\
0.24 \\
0.13 \\
4\end{array}$ \\
\hline $\begin{array}{l}1348427123594 \\
207233\end{array}$ & $\begin{array}{l}\text { Dua } \\
\text { Obat } \\
\text { Selamat } \\
\text { Nyawa } \\
\text { Pasien } \\
\text { COVID-19 } \\
\text { temu } \\
\text { \#Infus } \\
\text { \#Virus } \\
\text { \#Wabah }\end{array}$ & $\begin{array}{l}0.35 \\
2 \\
0.52 \\
0.02 \\
2 \\
0.13 \\
0 \\
0.22 \\
0.19 \\
1\end{array}$ \\
\hline
\end{tabular}

\begin{tabular}{|l|l|l|}
\hline & \#Radang & 0.22 \\
& \#Vaksin... & 0.99 \\
& & 0 \\
& & 0.12 \\
& & 0.11 \\
& & 0.12 \\
& & 0.22 \\
657475 & Vaksin & 0.22 \\
& buat & 0.12 \\
& Tiongkok & 0.32 \\
& kembali & 2 \\
& tanya, & 0.23 \\
& orang & 0 \\
& tua & 0.22 \\
& tidakboleh & 0.91 \\
& suntik! & 0.22 \\
& & 0.90 \\
& & 0.2 \\
\hline 1348434452775 & Walaupun & 0.42 \\
& vaksin, & 0.22 \\
& tetangga & 0.12 \\
& masih & 0.32 \\
& terkena & 2 \\
& covid & 0.23 \\
& \#vaksingagal & 0 \\
& & 0.19 \\
& & 0.23 \\
\hline
\end{tabular}

\subsection{Performa Model Yang Diusulkan}

Setelah model yang diusulkan dibuat dan dilakukan training, maka terdapat hasil dari performa model yang dibuat sebagai berikut (Tabel 10).

Tabel 10. Performa Model

\begin{tabular}{|l|l|l|l|}
\hline No & $\begin{array}{l}\text { Jumlah } \\
\text { Epoch }\end{array}$ & Split & Akurasi \\
\hline 1 & 10 & $70: 30$ & $72 \%$ \\
\hline 2 & 10 & $80: 20$ & $74 \%$ \\
\hline 3 & 15 & $70: 30$ & $82 \%$ \\
\hline 4 & 15 & $80: 20$ & $83 \%$ \\
\hline 5 & 20 & $70: 30$ & $84 \%$ \\
\hline 6 & 20 & $80: 20$ & $85 \%$ \\
\hline 7 & 25 & $70: 30$ & $85 \%$ \\
\hline 8 & 25 & $80: 20$ & $85 \%$ \\
\hline
\end{tabular}

Pada proses training, dilakukan perubahan jumlah epoch dan komposisi split dataset dan hasil akurasi terbaik didapat pada Jumlah Epoch 20 dan komposisi split 80:20. Adapun Ketika dinaikan epoch menjadi 25 akurasi tetap sama, maka tidak perlu lagi menambahkan jumlah epoch. 


\subsection{Evaluasi dan Pengujian Model}

Pada evaluasi dan pengujian, akan dicari nilai precision dan recall. Nilai tersebut didapatkan dari jumlah True Positif (TP), False Positif (FP), True Negatif (TN) dan False Negative (FN). Berikut merupakan jumlah TP, FP, TN dan FN pada Tabel 11.

Tabel 11. Nilai TP TF TN dan FN

\begin{tabular}{|l|l|l|}
\hline & Total Class & \multicolumn{1}{|c|}{ Jumlah } \\
\hline TP & 10.000 & 26.231 \\
FP & Negatif & 3859 \\
& 10.000 & \\
& Positif & \\
& 10.000 & \\
& Netral & \\
\hline TN & 10.000 & 21.231 \\
\cline { 1 - 1 } FN & Negatif & 8859 \\
& 10.000 & \\
& Positif & \\
& 10.000 & \\
& Netral & \\
& & \\
& &
\end{tabular}

Berdasarkan pada Tabel 11 didapatkan nilai berikut:

1. Precision

Dengan rumus TP / TP + FP

$$
\begin{aligned}
& =26231 / 26231+3859 \\
& =26231 / 30090 \\
& =\mathbf{0 . 8 7 1 7 5}
\end{aligned}
$$

2. Recall

$$
\begin{aligned}
\text { Dengan rumus TP } / \text { TP }+ \text { FP } \\
=26231 / 26231+8859 \\
=26231 / 35091 \\
=\mathbf{0 . 7 4 7 5}
\end{aligned}
$$

\section{Kesimpulan}

Berdasarkan

pembahasan sebelumnya, kesimpulan yang dapat ditarik dari penelitian ini sebagai berikut: Penelitian ini berhasil mengimplementasikan metode Probabilistic neural network untuk melakukan sentiment analisis terhadap tanggapan pemberian vaksin sinovac dan menghasilkan akurasi yang baik sebesar $85 \%$ dan dengan penambahan word embedding membantu proses klasifikasi lebih baik dengan perbedaan jika tidak menggunakan word embedding.

\section{Referensi}

Dini, A. (2021). Masyarakat Tak Perlu Ragu Vaksinasi, Vaksin COVID-19 AMAN. Nganjuk Kabupaten. https://www.nganjukkab.go.id/home/de tail-kabar/masyarakat-tak-perlu-raguvaksinasi-vaksin-covid-19-aman
Fajar, M., Annisa, N., \& Anggriana, A. J. (2021). Menyingkap Dampak -Dampak Sosial Kemasyarakatan Covid- 19.

Hastuti, P., Harefa, D. N., \& Napitupulu, J. I. M. (2020). Tinjauan Kebijakan Pemberlakuan Lockdown, Phk, Psbb Sebagai Antisipasi Penyebaran Covid19 Terhadap Stabilitas Sistem Moneter. Prosiding WEBINAR Fakultas Ekonomi Unimed "Strategi Dunia Usaha Menyikapi Status Indonesia Sebagai Negara Maju: Pra dan Pasca Covid-19", 57-70.

Junianto, E., \& Rachman, R. (2019). Implementation of Text Mining Model to Emotions Detection on Social Media Comments Using Particle Swarm Optimization and Naive Bayes Classifier. 2019 7th International Conference on Cyber and IT Service Management, CITSM 2019. https://doi.org/10.1109/CITSM47753.2 019.8965382

Onan, A. (2020). Sentiment analysis on product reviews based on weighted word embeddings and deep neural networks. Concurrency Computation , January, $\quad$ 1-12. https://doi.org/10.1002/cpe.5909

Rachman, F. F., \& Pramana, S. (2020). Analisis Sentimen Pro dan Kontra Masyarakat Indonesia tentang Vaksin COVID-19 pada Media Sosial Twitter. Health Information Management Journal ISSN, 8(2), 2655-9129. https://inohim.esaunggul.ac.id/index.ph $\mathrm{p} / \mathrm{INO} / \mathrm{article} / \mathrm{view} / 223$

Sarwani, M. Z., \& Mahmudy, W. F. (2016). Campus Sentiment Analysis E Complaint Using. 8(3), 135-140.

Setiawan. (2020). Terkait COVID-19 Kementerian Kesehatan. Kemenkes. https://www.kemkes.go.id/article/view/2 0030400008/FAQ-Coronavirus.html

Shree, N. V., \& Kumar, T. N. R. (2018). Identification and classification of brain tumor MRI images with feature extraction using DWT and probabilistic neural network. Brain informatics, 5(1), 23-30.. https://doi.org/10.1007/s40708017-0075-5 